DOI: $10.1515 /$ pts-2017-0002

\title{
INDUCTOR MACHINES WITH LONGITUDINALLY-TRANSVERSAL COMB-WISE TOOTH ZONE
}

\author{
A. Serebryakov ${ }^{1}$, N. Levin ${ }^{2}$, E. Kamolins ${ }^{1}$, M. Mileiko ${ }^{1}$ \\ ${ }^{1}$ Riga Technical University \\ Faculty of Power and Electrical Engineering \\ 12/1 Azenes Str., Riga, LV-1048, LATVIA \\ ${ }^{2}$ Institute of Physical Energetics, \\ 11 Krivu Str., LV-1006, Riga, LATVIA \\ e-mail: edmunds.kamolins@rtu.lv
}

\begin{abstract}
The method considered in the present paper concerns the operational efficiency of the inductor electric machine, which can be improved by placing on the stator and rotor teeth the combs combined from differently shaped teeth and slots. The use on the inductor electric machine stator and rotor teeth of combs as a combination of differently shaped hills (teeth) and valleys (slots) allows raising the specific power of the machine. This effect is determined by the chosen type of a comb element as well as by technological possibilities of the manufacturer. The proposed method could be used moderately in the inductor machines with longitudinally-transversal combing.
\end{abstract}

Keywords: comb teeth, inductor machines, magnetic permeance.

\section{INTRODUCTION}

In the inductor electric machine (IEM), the magnetic flow produced by the excitation system (i.e., by a winding or a permanent magnet) is branched into the flows over the stator teeth. When the tooth-like rotor runs, these flows change depending on the relative position of the stator and rotor teeth. When a rotor tooth is located against a stator tooth, the permeance of the air gap between the teeth as well as the tooth flow, $\left(\Lambda_{\max }\right)$ and $\left(\Phi_{\max }\right)$, respectively, are maximal. Change in the flow from $\Phi_{\max }$ to $\Phi_{\min }$ (the flow pulsation) causes the corresponding changes in the magneticflux linkage of the armature winding and EMF inducing there.

The IEM operational efficiency is determined by the difference $\Delta \Phi=\Phi_{\max }-\Phi_{\min }$ (or, respectively, $\Delta \Lambda=\Lambda_{\max }-\Lambda_{\min }$ ); therefore, the measures taken for increasing $\Phi_{\max }\left(\Lambda_{\max }\right)$ and decreasing $\Phi_{\min }\left(\Lambda_{\min }\right)$ favour the improvement of its technical indices.

One of the measures directed towards the improvement of IEM operation is 
the use of stator and rotor teeth with specific combs, the nature and effectiveness of which are considered below.

\section{THE SHAPES OF COMBS OF STATOR AND ROTOR TEETH}

The comb of a stator (rotor) tooth is a combination of hills (teeth) and valleys (slots) of definite shape (Fig. 1).

The shape (profile) of the hills-teeth and valleys-slots in a comb might be rectangular (Fig. 1a), triangular (Fig. 1b), etc.

The air gap between the stator and rotor teeth can be presented:

a. for combs according to Fig. 1a-a combination of flat air gaps arranged at an angle and in parallel to the longitudinal axis of the machine;

b. for combs according to Fig. $1 \mathrm{~b}$ - a combination of flat air gaps arranged at an angle to the longitudinal axis of the machine;

The comb-wise zone of the machine can be presented as individual elements shown in Fig. 1 for the corresponding profiles of the teeth and slots of the stator and rotor tooth combs. Combined arrangement of these elements on the stator and rotor tooth surface along the axial length of these teeth sets up their comb-wise zone.

The geometrical characteristics of the comb elements are as follows:

- $b_{z r}\left(b_{z s}\right)$ is the width of the root of a rotor (stator) tooth;

- $b_{p r}\left(b_{p s}\right)$ is the width of the base of a rotor (stator) slot;

- $h_{z r}\left(h_{z s}\right)$ is the height of the root of a rotor (stator) tooth;

- $h_{p r}\left(h_{p s}\right)$ is the height of a rotor (stator) slot;

- $\quad l_{a}, l_{b}$ is the axial length of a comb element according to Fig. 1a, b, respectively, which is also the length of the element air gap without a comb;

- $\quad l_{a}^{\prime}, l_{b}^{\prime}$ is the length of the comb element air gap according to Fig. 1, a, b, respectively;

- $\quad k_{a}=l_{a}^{\prime} / l_{a} ; k_{b}=l_{b}^{\prime} / l_{b}$ are the coefficients of air gap extension;

- $\delta$ is the rated air gap of the machine.

Within the framework of the research, geometrical parameters of the tooth zone were set as applied to a low-speed IEM: the diameter of stator bore $D_{s} \approx 2 \mathrm{~m}$, the number of rotor teeth $Z_{R} \geq 200$, the axial length of the stator and rotor cores $L=200 \div 220 \mathrm{~mm}$.

Taking into account recommendations [1]-[3], the following geometrical parameters of the tooth zone of such a machine were chosen:

- $\quad$ the rated air gap $\delta=D_{s} / 400=5 \mathrm{~mm}$;

- the width of stator (rotor) teeth $b_{z s}=b_{z r}=20 \mathrm{~mm}$;

- the height of the rotor tooth $h_{z R}=30 \mathrm{~mm}$ (i.e., $h_{Z R}=6 \delta$ );

- the height of the stator tooth $h_{z s}=40 \mathrm{~mm}$.

The listed parameters are shown in Fig. 1 [4]-[6].

The geometrical parameters of the comb elements of the types under consideration are given in Table 1. 
a)

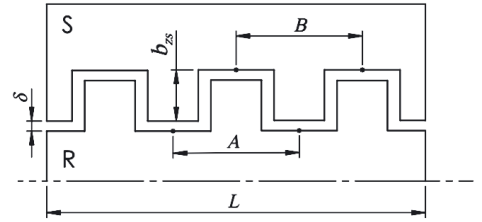

b)

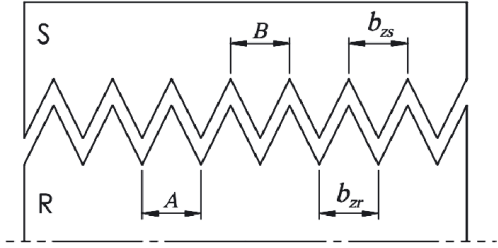

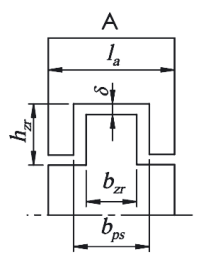

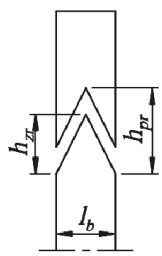

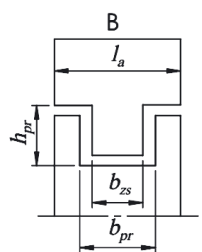

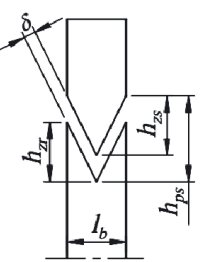

Fig. 1. Rectangular (a), triangular (b), and their elements of A and B types.

Geometrical Parameters of Comb Elements

\begin{tabular}{|c|c|c|}
\hline Type of element & R & T \\
Fig. 1a & Fig. 1b \\
\hline Parameter $(\mathrm{mm})$ & Fig. 1a & Fig. 1b \\
\hline$b_{z r}\left(b_{z s}\right)$ & 20 & 20 \\
\hline$b_{p r}\left(b_{p s}\right)$ & 30 & 20 \\
\hline$h_{z r}\left(h_{z s}\right)$ & 20 & 20 \\
\hline$h_{p r}\left(h_{p s}\right)$ & 25 & 25 \\
\hline$\delta$ & 5 & 5 \\
\hline$l_{a, b}$ & 50 & 20 \\
\hline$l_{a, b}^{\prime}$ & 90 & 40 \\
\hline$K_{l}=l^{\prime} / l$ & 1.8 & 2 \\
\hline
\end{tabular}

\section{THEORETICAL FOUNDATIONS}

The permeance of a flat air gap ("protrusion" is not taken into account) is calculated as that between parallel rectangular surfaces facing one another (Fig. 2) according to the formula [4]-[6]:

$$
\Lambda=\frac{S \mu_{0}}{\delta}=\frac{a b \mu_{0}}{\delta}
$$

where $S, a, b, \delta$ are the air gap area, width, length, and height (thickness), respectively; $\mu_{0}=4 \pi \cdot 10^{-7} \mathrm{H} / \mathrm{m}$ is the magnetic constant. 
In the analysis of permeance variation for a tooth zone of the IEM with a rectangular flat air gap and with a comb (i.e., with a curvilinear air gap) the $a$ and $b$ values are invariable (while different for different types of comb). Therefore, the product $a b \mu_{0}$ can be taken as a conditional unit; then the permeance expressed in conditional permeance units (CPU) will be inversely proportional to the air gap value, i.e.,

$$
\Lambda=\frac{1}{\delta}, \mathrm{CPU}
$$

We assume that the base CPU is the permeance corresponding to the calculated data of a tooth zone without a comb $\left(\Lambda_{B}\right)$.

To compare the combs as to their permeance values, these are to be reduced to the base permeance, dividing the real permeance $(\Lambda(2))$ by the base one $\left(\Lambda_{B}\right)$.

The magnetic flux across the air layer expressed in conditional units for magnetic flux (CUMF) will be defined as

$$
\Phi=\Lambda F=\frac{F}{\delta}, \mathrm{CUMF}
$$

where $F$ is the MMF of excitation.

It is necessary to express the $\Lambda$ and $\Phi$ values in conditional units for comparative estimation of the effectiveness of using differently shaped tooth combs.

The permeance of the ring-wise air gap (Fig. 3) is determined as [4]-[6]

$$
\Lambda=\frac{\mu_{0} b \Theta}{\ln \left(1+\frac{\delta}{r}\right)},
$$

(for parameters $b, \Theta, \delta, r$ see Fig. 3).

\section{INFLUENCE OF COMB ON THE MAXIMUM PERMEANCE OF THE AIR GAP UNDER A STATOR TOOTH}

At the position of rotor tooth 1 against stator tooth 2 (at $b_{z s}$ and $b_{z r}$ being equal, Fig. 4$)$, the permeance of the air gap between them is maximal $\left(\Lambda_{\max }\right)$, and the corresponding magnetic flux - flow per unit is also maximal $\left(\Phi_{\max }\right)$.

Such being the case, the magnetic flow through the tooth zone can be presented as separate flows through characteristic sections of the air gap:

- flow $\Phi_{z}$ in the path "stator tooth - rated air gap - rotor tooth";

- flow $\Phi_{p}$ in the path "stator slot - rotor slot" (leakage flux). 


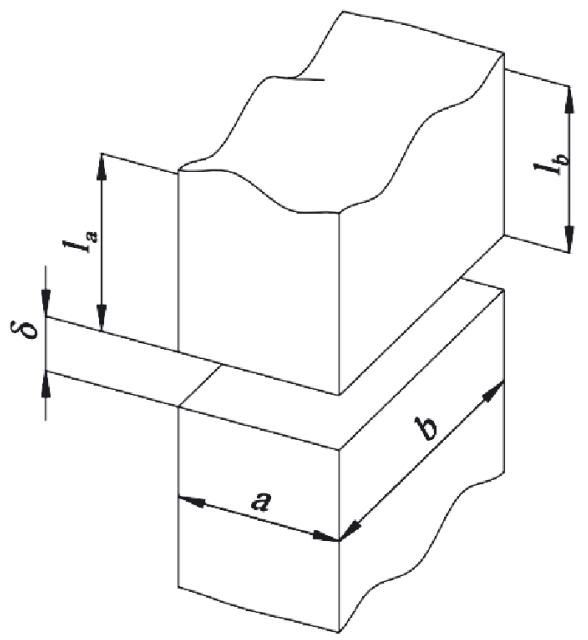

Fig. 2. Parallel rectangular surfaces facing one another.

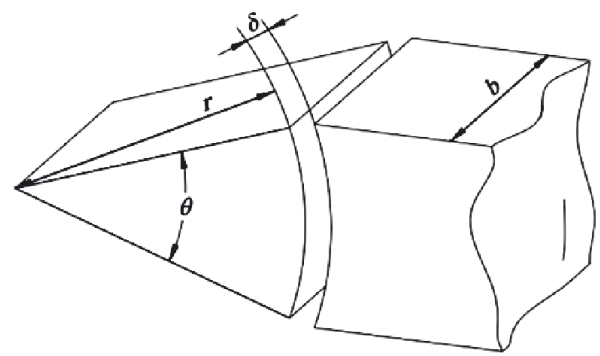

Fig. 3. Parameters of $b, \Theta, \delta, r$.

a)

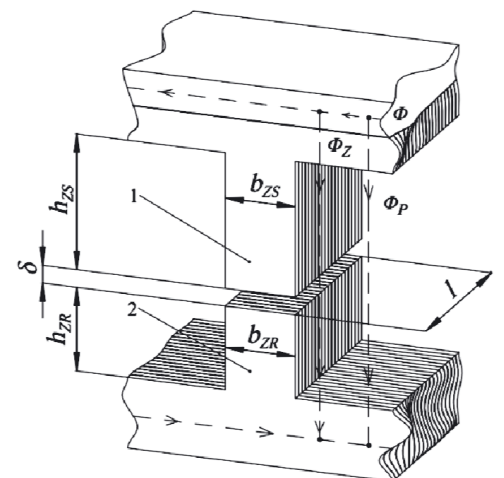

b)

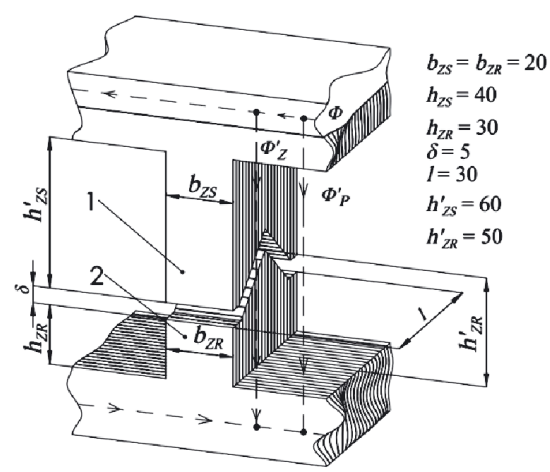

Fig. 4. Arrangement of stator teeth 1 and rotor teeth 2 corresponding to the maximum permeance of rectangular (a) and curvilinear (b) air gaps.

In compliance with the assumed designations for tooth zone parameters, expressions (1) and (4) are transformed, respectively, to the following ones: 


$$
\Lambda=\frac{b_{z s} l \mu_{0}}{\delta}
$$

Using teeth with differently shaped combs, the picture of flows passing through teeth and slots $\left(\Phi^{\prime}{ }_{z}\right.$ and $\Phi^{\prime}{ }_{p}$, respectively, Fig. 4) remains basically invariable, while their number will change. The relevant numerical values are given in Table 2.

As the first theoretical estimate for the extent of increase in the maximum permeance of the tooth zone with combs (and in the maximum flux, accordingly) we could take the air gap extension coefficient $K_{l(a, b)}$ (Table 1). All the more so because such an estimate seems to be valid since this increase occurs owing to that in the air gap length, whereas the calculated values of the efficiency coefficients $K_{(a, b)}$ and $K_{E(a, b)}$ given in Table 2 coincide with the corresponding values of coefficients $K_{l(a, b)}$.

However, using one or another shape of comb some peculiarities arise, which resist the theoretical analysis. Since the comb zone sections are arranged at an angle to the rectangular air gap of a comb-free machine, taking also into account the saturation of stator and rotor cores, the effectiveness of air gap extension decreases.

Therefore, in a comb zone with rectangular teeth and slots the magnetic flows through the side walls (taking into account the saturation of stator and rotor cores) are much weaker than the flows through the bases of teeth and slots of the comb. Assuming these flows to be approximately $10 \div 15 \%$ of the flows through bases a forecasted efficiency coefficient can be set for the extent of $\Lambda_{\max }$ and $\Phi_{\max }$ increasing:

$$
K_{E a}^{o}=(0.6 \div 0.65) K_{E a} .
$$

The values of this coefficient are given in Table 2. Using for the tooth and slot walls the steel sheets of $3 \div 5$ times greater thickness with respect to other saturating sheets $(0.5 \div 1 \mathrm{~mm})$, we can derive the efficiency coefficient for the maximum flow as

$$
K_{E a}^{o}=(0.63 \div 0.67) K_{E a} .
$$

The greatest increase in the air gap length is in the comb zone with triangular teeth and slots $\left(K_{b}=2\right)$. However, due to the angular arrangement of flat air gaps and saturation, the air gap size in the zones of triangle vertices (i.e., of teeth and slots) increases two times, while the flow correspondingly decreases. The extent of increase in $\Phi_{\max }$ depending on the slope of tooth and slot walls with respect to their bases can be approximately estimated as follows:

$$
K_{E b}^{o}=(0.6 \div 0.65) K_{E b}
$$

for $K_{E b}^{o}$ values see Table 2 .

The slot permeances and the corresponding flows through the slots (see Table 2) do not practically affect the $\Lambda_{\max }$ and $\Phi_{\max }$ values. 
Values Calculated for Rectangular and Triangular Combs

\begin{tabular}{|c|c|c|c|c|c|c|}
\hline \multirow[b]{2}{*}{ Calculated value } & \multicolumn{3}{|c|}{$\begin{array}{l}\text { Rectangular } \\
\text { Fig. 1a }\end{array}$} & \multicolumn{3}{|c|}{$\begin{array}{l}\text { Triangular } \\
\text { Fig. 1b }\end{array}$} \\
\hline & $\begin{array}{l}\text { Desig- } \\
\text { nation }\end{array}$ & Formula & $\begin{array}{c}A \cdot \mu_{0} \\
\mathrm{H} \\
\end{array}$ & $\begin{array}{l}\text { Desig- } \\
\text { nation }\end{array}$ & Formula & $\begin{array}{c}B \cdot \mu_{0} \\
\mathrm{H}\end{array}$ \\
\hline $\begin{array}{l}\text { Maximum permeance of } \\
\text { a stator element without a } \\
\text { comb (basic) }\end{array}$ & $\Lambda_{s a}$ & $\frac{b_{z s} l_{a} \mu_{0}}{\delta}$ & 0.20 & $\Lambda_{s b}$ & $\frac{b_{z s} l_{b} \mu_{0}}{\delta}$ & 0.08 \\
\hline $\begin{array}{l}\text { Maximum permeance of a } \\
\text { stator element with a comb }\end{array}$ & $\Lambda_{z a}$ & $\frac{b_{z s} l^{\prime}{ }_{a} \mu_{0}}{\delta}$ & 0.36 & $\Lambda_{z b}$ & $\frac{b_{z s} l_{b}^{\prime} \mu_{0}}{\delta}$ & 0.16 \\
\hline $\begin{array}{l}\text { Theoretical coefficient of } \\
\text { the comb element effi- } \\
\text { ciency }\end{array}$ & $K_{a}$ & $\Lambda_{z a} / \Lambda_{s a}$ & 1.8 & $K_{b}$ & $\Lambda_{z b} / \Lambda_{s b}$ & 2.0 \\
\hline $\begin{array}{l}\text { Number of comb elements } \\
\text { on the core length of } 200 \\
\mathrm{~mm}\end{array}$ & $v_{a}$ & $L / l_{a}$ & 4 & $v_{b}$ & $L / l_{b}$ & 10 \\
\hline $\begin{array}{l}\text { Maximum permeance of } \\
\text { stator core without a comb } \\
\text { (basic) }\end{array}$ & $\Lambda_{\max }^{a}$ & $\Lambda_{s a} v_{a}$ & 0.8 & $\Lambda_{\max }^{b}$ & $\Lambda_{s b^{v}}{ }_{b}$ & 0.8 \\
\hline $\begin{array}{l}\text { Maximum permeance of } \\
\text { stator core with combs }\end{array}$ & $\Lambda_{\max }^{L a}$ & $\Lambda_{z a} v_{a}$ & 1.44 & $\Lambda_{\max }^{L b}$ & $\Lambda_{z b^{v}} v_{b}$ & 1.6 \\
\hline $\begin{array}{l}\text { Theoretical coefficient } \\
\text { of comb efficiency with } \\
\text { respect to } \Lambda_{\max }\left(\Phi_{\max }\right)\end{array}$ & $K_{E a}$ & $\Lambda_{\max }^{L a} / \Lambda_{\max }^{a}$ & 1.8 & $K_{E b}$ & $\Lambda_{\max }^{L b} / \Lambda_{\max }^{b}$ & 2.0 \\
\hline $\begin{array}{l}\text { Slot permeance of a tooth } \\
\text { zone without a comb } \\
\text { (basic) }\end{array}$ & $\Lambda_{p a}$ & $\frac{b_{p s} l_{a} \mu_{0}}{h_{z s}+\delta+h_{Z R}}$ & 0.02 & $\Lambda_{p b}$ & $\frac{b_{p s} l_{b} \mu_{0}}{h_{z s}+\delta+h_{z R}}$ & 0.008 \\
\hline $\begin{array}{l}\text { Slot permeance of a tooth } \\
\text { zone with a comb }\end{array}$ & $\Lambda_{p a}^{\prime}$ & $\frac{b_{p s} l^{\prime}{ }_{a} \mu_{0}}{h_{z S}^{\prime}+\delta+h_{Z R}}$ & 0.026 & $\Lambda_{p b}^{\prime}$ & $\frac{b_{p s} l^{\prime}{ }_{b} \mu_{0}}{h_{z S}^{\prime}+\delta+h_{Z R}}$ & 0.01 \\
\hline $\begin{array}{l}\text { Coefficient of slot perme- } \\
\text { ance variation }\end{array}$ & $K_{p a}$ & $\frac{\Lambda_{p a}^{\prime}-\Lambda_{p a}}{\Lambda_{p a}^{\prime}}$ & 0.23 & $K_{p b}$ & $\frac{\Lambda_{p b}^{\prime}-\Lambda_{p b}}{\Lambda_{p b}^{\prime}}$ & 0.2 \\
\hline $\begin{array}{l}\text { Coefficient of the influ- } \\
\text { ence of slot permeance on } \\
\Lambda_{\max } \text { of the core }\end{array}$ & $K_{m a}$ & $\Lambda_{p a}^{\prime} v_{a} / \Lambda_{\max }^{L a}$ & 0.07 & $K_{m b}$ & $\Lambda_{p b}^{\prime} v_{b} / \Lambda_{\max }^{L b}$ & 0.06 \\
\hline $\begin{array}{l}\text { Forecasted coefficient } \\
\text { of comb efficiency with } \\
\text { respect to } \Lambda_{\max }\left(\Phi_{\max }\right)\end{array}$ & $K_{E a}^{o}$ & $(0.6 \div 0.63) K_{E a}$ & $1.1 \div 1.15$ & $K_{E b}^{o}$ & $(0.6 \div 0.65) K_{E b}$ & $1.2 \div 1.3$ \\
\hline
\end{tabular}

Note: $A, B$ are the numerical values of physical quantities.

The maximum permeance of the air gap of stator core without a comb $\Lambda_{\text {max }}=\frac{b_{z s} L \mu_{0}}{\delta}=0.8 \mu_{0}, H$. 


\section{COMB INFLUENCE ON THE MINIMUM PERMEANCE OF THE AIR GAP UNDER A STATOR TOOTH}

At arrangement of rotor tooth 1 between stator teeth 2 (i.e., against a stator slot, see Fig. 5), the permeance of the air gap between stator and rotor is minimal $\left(\Lambda_{\min }\right)$; correspondingly, the magnetic flux is also minimal $\left(\Phi_{\min }\right)$. The latter can be presented as flows/fluxes through characteristic sections of the air gap:

- the flow over the central part of a stator tooth $\left(\Phi_{c z s}\right)$ passing through the section of the air gap, with maximum of $\delta_{\max }=\delta+h_{z R}$ ( $\delta$ is the nominal/ rated gap; $h_{z R}$ is the height of the rotor tooth);

- the flow over the side parts of stator and rotor teeth $\Phi_{b z}$ passing through the air gap sections with the nominal/rated gap $\delta$;

- the flow over the central part of a rotor tooth $\left(\Phi_{c z s}\right)$ passing through stator slot 3 and the air gap section with gap $\delta$, i.e., through the summary air gap $\delta_{\Sigma}=\delta+h_{z s}\left(h_{z s}\right.$ is the height of the stator tooth), being therefore a leakage flux.

The minimal flow of stator tooth can be presented in the form:

$$
\Phi_{\min }=\Phi_{c z s}+\Phi_{b z}
$$

When we use in the machine the stator and rotor teeth with a longitudinal comb, the picture of flow passage corresponding to $\Phi_{\min }$ would not basically change (Fig. 6). However, the number of flows according to (6) will change, which is connected with changes in the geometrical sizes of some sections on the way of flow passage, and, accordingly, in their permeance (with stator teeth $b_{z s}$ and rotor teeth $b_{z R}$ being invariable).

Two basic variants arise as to the arrangement of stator and rotor teeth with combs:

- at the arrangement of a comb in stator slot $3^{`}$ of comb slot 4`, which applies to the cross-section passing through the axes of comb slots and teeth (see Fig. 6, a);

- $\quad$ at the arrangement in stator slot $3^{`}$ of comb tooth $5^{`}$ (Fig. 6b).

In the process of calculation of permeances and flows taking into account the air gap values on the ways of passage of central $\Phi_{c z s}$ and lateral $\Phi_{b z}$ stator tooth flows, it is assumed that the stator tooth width for passage of these flows ( $\Phi_{c z s}$ and $\left.\Phi_{b z}\right)$ is $0.5 b_{z s}$ and $0.25 b_{z s}$, respectively. This is reflected in the calculation formulas shown in Table 3 along with the calculation results.

Related permeances (we will call them "slot-slot" type) and second ones ("slot-tooth" type) are shown in Fig. 6a and b respectively, where those are arranged at the core half-length each, taking into account the air gap extension. 


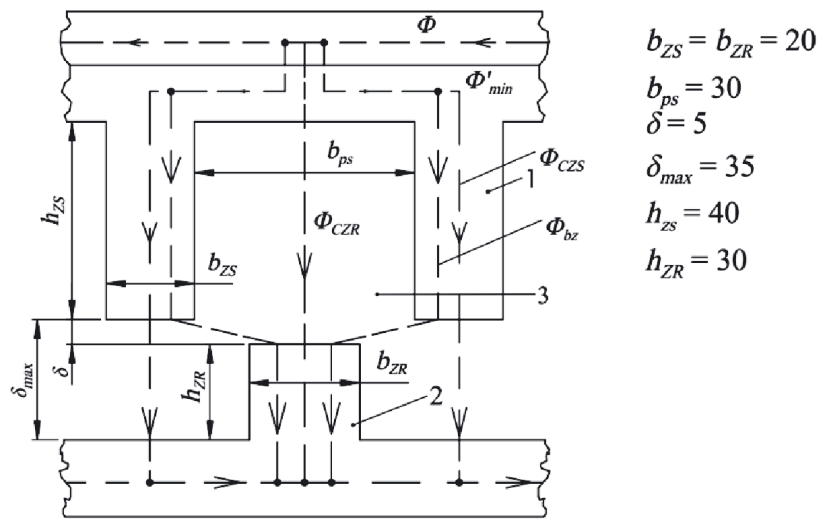

Fig. 5. Arrangement of stator teeth 1 and rotor teeth 2 corresponding to the minimal permeance of a rectangular air gap.

a)

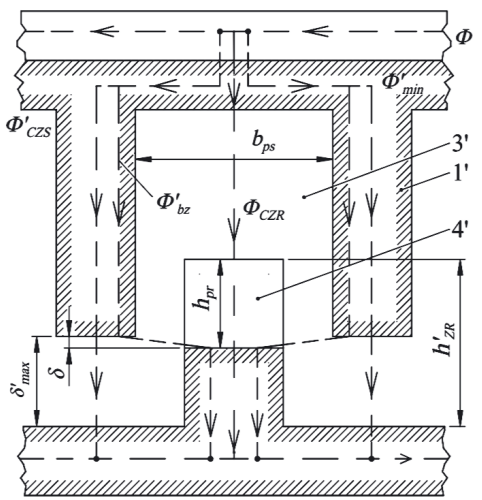

b)

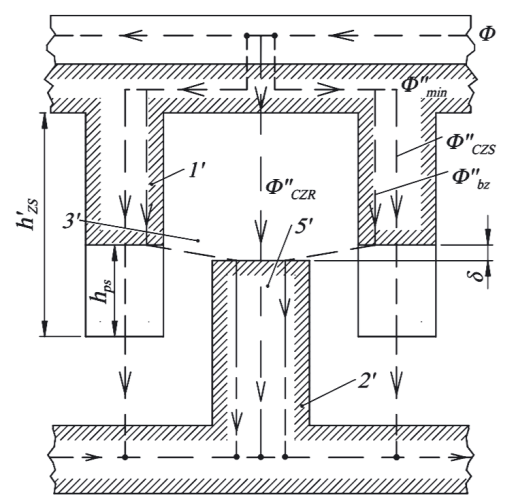

Fig. 6. Arrangement of stator teeth 1 and rotor teeth 2 with combs corresponding to the minimal permeance of a curvilinear air gap at a) placement in stator slot $3^{\prime}$ of comb slot $4^{\prime}$;

b) placement in stator slot $3^{`}$ of comb tooth 5 ; sizes $(\mathrm{mm})$ : $\delta_{\text {max }}^{\prime}=20 ; h_{z s}^{\prime}=60 ; h_{z r}^{\prime}=50 ; h_{p s}=25 ; h_{p r}=25$.

The summarised influence of combs favours the increase in permeance and flow pulsations $\Delta \Lambda=\Lambda_{\max }-\Lambda_{\min }$ and, consequently, the increase in induced EMF and power of the machine as well as in the specific power, since the effect of increase in the weight of stator and rotor cores due to the use of combs is significantly weaker as compared with that of increased power.

The theoretical value of permeance pulsation coefficient $K_{\Lambda}=\frac{\Delta \Lambda_{a, b}}{\Delta \Lambda}$ for all considered types of comb in reality coincides with that for air gap extension coefficient $K_{l}$ (Table 1). This allows for the choice of forecasted coefficients of comb efficiency $K_{E \Lambda}^{\Pi}$ (Table 3 ) that would be equal to the corresponding comb efficiency coefficients $K_{E(a, b)}^{o}$ (Table 2) as related to the maximal flow.

To verify the statements mentioned above, the mathematical modelling has been performed for the elements of comb-wise tooth zones, which confirms, in principle, that it is possible to employ the effect of combs but with slightly smaller (by $10 \div 15 \%$ ) values of real efficiency coefficients $K_{E(a, b)}^{r}$ given in Table 3 . 
It is quite natural that the designer should employ the effect from the use of combs taking into account the production expenses.

Table 3

Formula of Modelling

\begin{tabular}{|c|c|c|c|c|c|c|c|c|c|}
\hline \multicolumn{3}{|c|}{$\begin{array}{l}\text { Rectangular air gap } \\
\text { (without comb) }\end{array}$} & Type of comb & \multicolumn{3}{|c|}{$\begin{array}{l}\text { Rectangular } \\
\text { Fig. 1a }\end{array}$} & \multicolumn{3}{|c|}{$\begin{array}{l}\text { Triangular } \\
\text { Fig. } 1 \mathrm{~b}\end{array}$} \\
\hline $\begin{array}{l}\text { Desig- } \\
\text { nation }\end{array}$ & Formula & $\begin{array}{c}Y \cdot \mu_{0} \\
\mathrm{H}\end{array}$ & Calculated value & $\begin{array}{l}\text { Desig- } \\
\text { nation }\end{array}$ & Formula & $\begin{array}{c}A \cdot \mu_{0} \\
\mathrm{H}\end{array}$ & $\begin{array}{l}\text { Desig- } \\
\text { nation }\end{array}$ & Formula & $\begin{array}{c}B \cdot \mu_{0} \\
\mathrm{H}\end{array}$ \\
\hline$\Lambda_{c p s}$ & $\frac{0.5 b_{Z R} L \mu_{0}}{2 \delta\left(\delta+h_{Z R}\right)}$ & 0.03 & $\begin{array}{l}\text { Permeance for } \\
\Phi_{c z s} \text { of half-comb } \\
\text { slots }\end{array}$ & $\Lambda_{c p}^{a}$ & $\frac{0.5 b_{z s} l^{\prime}{ }_{a} v_{a} \mu_{0}}{2 h_{Z R}}$ & 0.06 & $\Lambda_{c p}^{b}$ & $\frac{0.5 b_{z s} l_{b}^{\prime} v_{b} \mu_{0}}{2 h_{Z R}}$ & 0.066 \\
\hline$\Lambda_{b p}$ & $\frac{0.25 b_{Z R} L \mu_{0}}{2\left(b_{p s}-b_{Z R}\right)}$ & 0.05 & $\begin{array}{l}\text { Permeance for } \Phi_{b z} \\
\text { of half-comb slots }\end{array}$ & $\Lambda_{b p}^{a}$ & $\frac{0.25 b_{z s} l_{a}^{\prime} v_{a} \mu_{0}}{2\left(b_{p s}-b_{Z R}\right)}$ & 0.09 & $\Lambda_{b p}^{b}$ & $\frac{0.25 b_{z s} l_{b}^{\prime} v_{b} \mu_{0}}{2\left(b_{p s}-b_{Z R}\right)}$ & 0.100 \\
\hline \multirow[t]{5}{*}{$\Lambda_{\min }^{p}$} & $\Lambda_{c p s}+\Lambda_{b p}$ & 0.08 & $\begin{array}{l}\text { Permeance for } \\
\Phi_{\text {min }} \text { of half-comb } \\
\text { slots }\end{array}$ & $\Lambda_{\min }^{p a}$ & $\Lambda_{c p}^{a}+\Lambda_{b p}^{a}$ & 0.15 & $\Lambda_{\min }^{p b}$ & $\Lambda_{c p}^{b}+\Lambda_{b p}^{b}$ & 0.166 \\
\hline & & & $\begin{array}{l}\text { Permeance for } \Phi_{c z s} \\
\text { of half-comb teeth }\end{array}$ & $\Lambda_{c z}^{a}$ & $\frac{0.5 b_{z s} l_{a}^{\prime} v_{a} \mu_{0}}{2\left(h_{p s}+h_{Z R}\right)}$ & 0.036 & $\Lambda_{c z}^{b}$ & $\frac{0.5 b_{z s} l_{b}^{\prime} v_{b} \mu_{0}}{2\left(h_{p s}+h_{z R}\right)}$ & 0.04 \\
\hline & & & $\begin{array}{l}\text { Permeance for } \Phi_{b z} \\
\text { of half-comb teeth }\end{array}$ & $\Lambda_{b z}^{a}$ & $\frac{0.25 b_{z s} l_{a}^{\prime} v_{a} \mu_{0}}{2\left(h_{p s}+h_{Z R}\right)}$ & 0.09 & $\Lambda_{b z}^{b}$ & $\frac{0.25 b_{z s} l_{b}^{\prime} v_{b} \mu_{0}}{2\left(h_{p s}+h_{Z R}\right)}$ & 0.10 \\
\hline & & & $\begin{array}{l}\text { Permeance for } \\
\Phi_{\text {min }} \text { of half-comb } \\
\text { teeth }\end{array}$ & $\Lambda_{\min }^{z a}$ & $\Lambda_{c z}^{a}+\Lambda_{b z}^{a}$ & 0.126 & $\Lambda_{\min }^{z b}$ & $\Lambda_{c z}^{b}+\Lambda_{b z}^{b}$ & 0.14 \\
\hline & & & $\begin{array}{l}\text { The mean minimal } \\
\text { permeance }\end{array}$ & $\Lambda_{a}$ & $\frac{\Lambda_{\min }^{p a}+\Lambda_{\min }^{z a}}{2}$ & 0.138 & $\Lambda_{b}$ & $\frac{\Lambda_{\min }^{p b}+\Lambda_{\min }^{z b}}{2}$ & 0.153 \\
\hline$K_{m}$ & $\frac{\Lambda_{\min }^{p}}{\Lambda_{\max }}$ & 0.1 & $\begin{array}{l}\text { The } \\
\text { minimum/maximum } \\
\text { permeance core ratio } \\
\text { of the core }\end{array}$ & $K_{m}^{a}$ & $\Lambda_{a}+\Lambda_{\max }^{a}$ & 0.096 & $K_{m}^{b}$ & $\Lambda_{b}+\Lambda_{\max }^{b}$ & 0.096 \\
\hline \multirow[t]{4}{*}{$\Delta \Lambda$} & $\frac{\Lambda_{\max }}{\Lambda_{\min }^{p}}$ & 0.72 & $\begin{array}{l}\text { Difference between } \\
\text { the maximal and } \\
\text { minimal permeances } \\
\text { of the core }\end{array}$ & $\Delta \Lambda_{a}$ & $\Lambda_{\max }^{a}-\Lambda_{a}$ & 1.302 & $\Delta \Lambda_{b}$ & $\Lambda_{\max }^{b}-\Lambda_{b}$ & 1.447 \\
\hline & & & $\begin{array}{l}\text { Theoretical } \\
\text { coefficient of comb } \\
\text { efficiency (overall) }\end{array}$ & $K_{E a}^{t}$ & $\Delta \Lambda_{a} / \Delta \Lambda$ & 1.81 & $K_{E b}^{t}$ & $\Delta \Lambda_{b} / \Delta \Lambda$ & 2.01 \\
\hline & & & $\begin{array}{l}\text { Forecasted coefficient } \\
\text { of comb efficiency }\end{array}$ & $K_{E a}^{\Pi}$ & - & $\begin{array}{l}1.1 \div \\
1.15\end{array}$ & $K_{E b}^{\Pi}$ & - & $\begin{array}{l}1.2 \div \\
1.3\end{array}$ \\
\hline & & & $\begin{array}{l}\text { Real coefficient of } \\
\text { comb efficiency }\end{array}$ & $K_{E a}^{r}$ & $\begin{array}{l}\text { Result of } \\
\text { modelling }\end{array}$ & 1.21 & $K_{E b}^{r}$ & $\begin{array}{l}\text { Result of } \\
\text { modelling }\end{array}$ & 1.16 \\
\hline
\end{tabular}

From the results it follows that even though the use of combs increases to an extent $\Lambda_{\text {min }}$ and $\Phi_{\text {min }}$, the influence of this increase is weaker than that in a comb-free tooth zone (see $K_{m}$ coefficient value).

\section{CONCLUSIONS}

The use on the IEM stator and rotor teeth of combs as a combination of differently shaped hills (teeth) and valleys (slots) allows raising the specific power of the machine. This effect is determined by the chosen type of a comb element as well as 
by technological possibilities of the manufacturer.

At the same time, it is necessary to take into account that the use of longitudinally-transversal combing can lead to a forced decrease in the MMF excitation (to avoid possible saturation of steel), which would reduce the effect of power increase - or even exclude it.

All this should be taken into account and used moderately in the inductor machines with longitudinally-transversal combing.

\title{
ACKNOWLEDGEMENTS
}

The present research has been supported by the State Research Programme “LATENERGI”.

\section{REFERENCES}

1. Levin, N. N., \& Serebryakov, A.D. (1976). Electric machines and drives. In Proceedings of RVVKKU (Vol. 3). Riga (in Russian).

2. Santalov, A. M., \& Serebryakov, A.D. (1976). On the optimal geometry of the tooth zone of inductor machines. In Proceedings of RKIIGA (Vol. 113, pp. 12-23). Riga (in Russian).

3. Serebryakov, A. D. (1982). Optimal tooth zone of the inductor motor. Contactless electric machines (Vol. 21, pp. 157-162). Riga: Zinatne (in Russian).

4. Alper, N. J. (1962). Calculation of magnetic fields in the air gap of the inductor machine with constant flow. In Bulletin of Electronic Industry, Vol. 3. Moscow (in Russian).

5. Bul, B. K. (1964). Foundations of Theory and Calculation of the Magnetic Fields. Moscow: Energy (in Russian).

6. Koc, B. E. (1964). Determination of air gap permeances in comb-wise magnetic systems. Elecrotechnics, 9. Moscow (in Russian).

\section{INDUKTORMAŠĪNAS AR GARENISKI-TRANSVERSĀLĀM KQEMMVEIDA ZOBU ZONĀM}

\author{
A. Serebrjakovs, N. Levins, E. Kamoliņš, M. Mileiko
}

Kopsavilkums

Dotajā darbā piedāvātā metode attiecināma uz induktortipa elektriskās mašīnas efektivitātes paaugstināšanu, ko var realizēt, izveidojot mašīnas statora un rotora zobus ar dažāda veida gareniski-transversiālām ķemmveida zobu zonām. Izmantojot induktortipa mašīnās ķemmveida statoru un rotoru un, kombinējot tos ar dažādas formas zobiem un rievām, ir iespējams paaugstināt elektriskās mašīnas īpatnējo momentu. Šis efekts ir atkarīgs no izvēlētā ķemmveida formas elementa kā arī no ražotāja tehnolog̣iskajām iespējām. Piedāvātā metode var būt saprātīgi pielietota induktortipa mašīnās ar gareniski-transversiālu ķemmveida zobu zonu.

02.12 .2016 . 